\section{Perheen kokemus lapsen syntymisestä kotona}

Suomi juhlii tänä vuonna satavuotista historiaansa ja voimme olla ylpeitä monista erilaisista saavutuksista ja monenlaisesta kehityksestä, jota maassamme on tapahtunut. Yksi merkittävä ylpeyden aihe on suomalainen äitiyshuolto ja sen tulokset. Maamme perinataalikuolleisuus eli kuolleena syntyneiden tai ensimmäisen elinviikkonsa aikana kuolleiden lasten määrä on pitkään ollut maailman alhaisimpia. Vuonna 1917 tuhannesta vastasyntyneestä hieman yli 46 lasta syntyi kuolleena tai kuoli ensimmäisen elinviikkonsa aikana. Nykyisin vastaava luku on neljä lasta tuhannesta. Äitiyshuollon myönteistä kehitystä voidaan selittää useilla eri tekijöillä, kuten yhteiskunnallisilla muutoksilla, terveydenhuollon palvelujärjestelmän kehittymisellä, kätilökoulutuksella ja lääketieteen kehittymisellä.

Synnytykseen ja äitiyteen liittyvää kulttuurin muutosta on kuvattu Hilkka Helstin vuonna 2000 valmistuneessa etnologian alaan kuuluvassa väitöskirjatyössä. Aina 1800luvun puolesta välistä seuraavan vuosisadan alkuun asti käsitykset synnyttämisestä perustuivat kansanuskoon ja kansanparannukseen. Myös luterilainen uskonto ja erilaiset he- rätysliikkeet sekä sääty-yhteiskunta vaikuttivat synnyttämisen kulttuuriin. Vielä 1900luvun alkupuolella joillakin alueilla Suomessa uskottiin reproduktiotabuun. Käsite tarkoittaa raskaana olevan, synnyttävän ja lapsivuoteisen naisen pitämistä saastaisena, mistä johtuen synnyttänyt nainen oli tapana kirkottaa. Kirkottaminen tarkoittaa synnyttäneen naisen puhdistamista synnytyksen aiheuttamasta epäpuhtaudesta ja siunauksen antamista sekä kiitosrukouksen esittämistä.

Koti oli tavallisin syntymäpaikka 1900- luvun puoleen väliin asti. 1800-luvun lopulla synnytettiin yleisesti myös saunoissa, navetoissa ja kesäisin ulkona. Synnytyspaikan valintaan vaikutti esimerkiksi tarve synnytyksen salaamiselle, taikojen ja loitsujen teon mahdollistaminen sekä pahan silmän välttäminen. Kansanomaiset käsitykset ja parannuskeinot väistyivät, kun synnytykset siirtyivät sairaaloihin 1900-luvun aikana. 1930-luvun lopulla yksi kolmesta naisesta synnytti sairaalassa, mutta 1950-luvulle siirryttäessä jo 90 prosenttia. Edellä kuvattu muutos johtui etenkin keskussairaalaverkoston luomisesta, mutta myös lääketieteen ja terveydenhuollon kehittymisestä sekä terveysvalistuksen aloittamisesta.

Ennen sairaalaan siirtymistä synnyttäminen oli osa jokapäiväistä elämää, ja kovan työn tekemisen uskottiin hel- pottavan synnytystä. Aikalaiskuvauksissa synnytyksen luonnollisuudella tarkoitettiin usein synnytyksen tapahtumista työn ja arkiaskareiden ohessa. Synnytyskipujen lievittämiseen käytettiin yleisesti alkoholia ja kansanparannusta. Suomessa ja muissa länsimaissa synnytysten sairaalaan siirtyminen johti siihen, että synnytys alettiin nähdä lääketieteellistä hoitoa vaativana tapahtumana. Tämä johti siihen, että synnyttäjät laitettiin sänkyyn makaamaan, jolloin erilaisten toimenpiteiden tekeminen kuten kivunlievityksen antaminen ja pihtien käyttö olisi helpompaa. Synnytyskivun lievittämisen modernit keinot kehittyivät 1970-luvulla, jolloin hengitysteitse otettavat lääkeaineet ja puudutukset sekä sikiön hyvinvoinnin seurantaan tarkoitetut menetelmät otettiin laajemmin käyttöön. Terveyden ja hyvinvoinnin laitoksen tilastojen mukaan vuonna 2015 noin puolet kaikista synnyttäjistä sai epiduraalipuudutuksen ja jotakin kivunlievitystä saivat lähes kaikki naiset. Keisarileikkauksella hoidettiin 16 prosenttia kaikista synnytyksistä.

Nykyiset Suomen äitiyshuollon tulokset ovat maailman parhaita. Tähän kehitykseen ovat vaikuttaneet edellä kuvattujen asioiden ohella myös 1900-luvun läpi edennyt lääketieteen yleinen kehittyminen, yleisen hygienian paraneminen ja antibioottien keksiminen. Myös maamme yli 200-vuoti- 
nen perinne kätilöiden kouluttamisessa ja neuvolajärjestelmän synty 1940-luvulla ovat olleet merkittäviä tekijöitä. Tämän lisäksi yleisen koulutustason nousu ja saatavilla olevat sosiaaliset etuudet sekä yleinen vaurastuminen ovat edistäneet äitiyshuollon tuloksia. Hyvistä tuloksistaan huolimatta suomalaista äitiyshuoltoa on kritisoitu medikalisaatiosta, joka tarkoittaa lääketieteen vallan laajenemista aiemmin ei-lääketieteellisinä pidetyille alueille. Medikalisaation on kuvattu johtaneen raskauden ja synnytyksen ymmärtämiseen lääketieteellisinä ilmiöinä ja teknologian lisääntyneeseen käyttöön sekä synnyttäjän roolin muuttumiseen lähinnä hoidon ja toimenpiteiden kohteena olemiseksi.

Kansallisella lainsäädännöllä on ollut keskeinen vaikutus äitiyshuollon kehittymiseen ja tulosten paranemiseen. Lainsäädännöllisistä uudistuksista merkittävin oli vuonna 1937 voimaan tullut äitiysavustuslaki. Avustus oli aluksi kohdennettu vain vähävaraisille synnyttäjille, jotka haluttiin saada terveydenhuollon palveluiden piiriin. Myöhemmin äitiysavustuslaki laajennettiin koskemaan kaikkia äitejä. Vuonna 1944 astuivat voimaan lait kunnallisista äitiys- ja lastenneuvoloista sekä kunnallisista kätilöistä ja terveyssisarista. Neuvolaverkosto muodostui kattavaksi ja käyttäjilleen maksuttomaksi. Vuonna 1972 voimaan tullut kansanterveyslaki on yksi merkittävimpiä sodanjälkeisen ajan terveydenhuollon uudistuksia, joka vaikutti terveyskeskusjärjestelmän syntyyn ja edisti neuvolapalveluiden kehittämistä.
Kansanterveyslaki kumottiin vuonna 2010 terveydenhuoltolailla. Lainsäädännön lisäksi raskaanaolevien ja synnyttäjien hoitoon on annettu suosituksia ja ohjeistuksia. Näistä keskeisiä ovat vuonna 2013 julkaistu Äitiysneuvolaopas ja vuonna 2014 julkaistu Seksuaali- ja lisääntymisterveyden toimintaohjelma. Viimeksi mainitussa todetaan, että syntymänhoidossa keskeisiä tavoitteita ovat syntymän aikaisen kokonaisvaltaisen tuen toteutuminen kaikkien synnyttäjien hoidossa ja synnyttäjän ja perheen tukeminen voimaannuttavaan synnytyskokemukseen. Lisäksi tavoitteena on synnyttäjien toiveiden ja tarpeiden mukaisen kivunlievityksen tarjoaminen siten, että synnyttäjät ovat tietoisia niihin liittyvistä eduista ja hatoista.

Äitiyshuollossa pyritään yhä parempiin tuloksiin ja edelleen lisääntyvään turvallisuuteen. Tästä johtuen vuonna 2015 voimaan astuneella Sosiaali- ja terveysministeriön asetuksella kiireellisen hoidon perusteista ja päivystyksen erikoisalakohtaisista edellytyksistä säädetään, että kunnan tai kuntayhtymän on huolehdittava, että synnytyksiä hoitavassa sairaalassa hoidetaan vähintään noin 1000 synnytystä vuodessa. Asetuksella pyritään edelleen parantamaan synnyttämisen turvallisuutta, mutta samalla tavoitellaan myös säästöjä ja resurssien tehokkaampaa käyttöä. Suomalaisissa synnytyssairaaloissa syntyy keskimäärin noin 2000 lasta vuodessa, mutta joka kolmannessa syntyy alle 1000 lasta, mikä on ollut Sosiaali- ja terveysministeriön vuonna 2015 asettama raja synnytystoiminnan jatkamiselle. Lukujen perusteella on siis odotettavissa, että synnytysyksiköiden lakkauttaminen tulee jatkumaan edelleen.

Nykyisin suomalainen nainen synnyttää keskimäärin 1,65 lasta ja sata vuotta sitten vastaava luku oli 3,71. Synnytysten määrä on siis merkittävästi vähentynyt ja vuonna 2016 synnytysten määrä oli yhtä alhainen kuin 1800-luvun alussa ja suurena nälkävuonna 1868. Tämän päivän ensisynnyttäjä on lähes 29-vuotias ja kaikkien synnyttäjien keskiikä on hieman yli 30 vuotta. Suomalaisten käytäntöjen mukaan nainen voi ottaa synnytykseen tuekseen puolisonsa tai tukihenkilön. Käytäntö yleistyi jo 1960-luvulla perhevalmennukseen osallistuneille isille. Nykyäidit ja isät voivat valmentautua ja tutustua synnytyssairaalaan ja sen tarjoamiin palveluihin virtuaalisesti internetin avulla. Teknologian kehittymisen ja digitalisaation myötä tutustumiskäynnit sairaalaan ovat vähentyneet.

Suomessa 99,6 prosenttia synnytyksistä tapahtuu sairaaloissa, jotka ovat julkisesti rahoitettuja. Maassamme ei ole ollut tarjolla vaihtoehtoisia synnytyspalveluita, kuten kätilöjohtoisia yksiköitä tai yksityisiä synnytyssairaaloita. Viimeisen kymmenen vuoden aikana maahamme on kuitenkin perustettu yksityisiä neuvolaja perhevalmennuspalveluita. Näyttää sille, että yksityiset palvelut ovat mahdollistaneet perheille valinnanmahdollisuuden, mutta huomionarvoista on että palvelut ovat maksullisia ja rajaavat siten pois osan käyttäjistä. Suomessa toimii 
myös kätilöyrittäjiä, jotka hoitavat kotisynnytyksiä perheiden toiveiden mukaisesti. Maassamme on vuosittain muutamia kymmeniä perheitä, jotka ovat tehneet valinnan synnyttää omassa kodissaan. Vuonna 2014 kotisynnytyksiä oli 29 ja vuonna 2015 jo 45. Suomen kotisynnytysmäärät ovat matalampia kuin muissa Pohjoismaissa, joista Tanskassa kotisynnytyksiä on määrällisesti eniten, hieman yli tuhat vuodessa. Islannissa kotisynnytyksiä on eniten suhteessa syntyneiden määrään. Tanskassa ja Islannissa kotisynnytys kuuluu julkiseen terveydenhuoltoon ja naisille on tarjolla myös muita vaihtoehtoisia synnytyspalveluita.

Suomessa jokaisen naisen suositellaan synnyttävän sairaalassa turvallisuuteen liittyvistä syistä. Kotona synnytettäessä mahdollisia hätätilanteita ei voida hoitaa samalla tavalla kuin sairaalassa. Kotisynnytys ei kuulu maassamme julkisen terveydenhuollon piiriin ja perheet vastaavat siten itse kaikista järjestelyistä ja kustannuksista. Vaikka suomalainen äitiyshuolto on korkeatasoista ja palvelut ilmaisia, näyttää sille että jotkut perheet etsivät vaihtoehtoja ja haluavat tehdä erilaisen valinnan.
Olen tutkinut tekemässäni väitöskirjatyössä perheiden, äitien, isien ja sisarusten, kokemusta lapsen tai sisaruksen syntymästä kotona. Tutkimuksen tarkoituksena oli tuottaa kuvailevaa ja tulkitsevaa tietoa kotona syntyneen lapsen perheen kokemuksista. Tutkimukseen osallistui 14 äitiä, 11 isää ja 7 lasta. Keräsin aineiston haastatteluina ja lasten piirustuksina. Tutkimus on tyypiltään laadullista, fenomenologista tutkimusta.

MaIja-RiITTA Jouhki

TtT (terveystieteiden tohtori)

Tampereen yliopisto 